\title{
ESTONIAN FOLK DANCE: TERMS AND CONCEPTS IN THEORY AND PRACTICE ${ }^{1}$
}

\author{
Sille Kapper
}

\begin{abstract}
The article provides an overview of the changes that have occurred in the concept of 'folk dance' in Estonia from the end of the 19th century until today. The diachronic analysis of both theoretical and practical discourses is based on Estonian-language paper and web publications where the word rahvatants (folk dance) has been used as a term or where the concept is defined; an inquiry among the members of a folk dance group, and my personal ethnographic fieldwork in the folk dance world of Estonia. My borderline position between the roles of a dance researcher and a dancer and folk dance teacher in practice makes it possible to switch between different discourses and find their intersections. Shifts that occur in terms and concepts used in both scientific and public classifications, as well as in specialised discourses situated between them, reflect varied trends in the Estonian dance tradition during the 20th century and explain the development of the present situation.
\end{abstract}

Keywords: folk dance, traditional folk dance, folklore, stage folk dance, national dance, choreography, dance as art form, performing arts

\section{INTRODUCTION}

In the minds of contemporary Estonians, the meaning of 'Estonian folk dance' is diverse, ranging from more or less staged presentations of earlier village dances to any kind of dancing that ordinary people practise in Estonia today. In everyday speech and popular discourse folk dance is often defined through the national costume worn by the dancers, no matter what the choreographic text that they perform. Former Folk Dance Celebrations ${ }^{2}$ have been renamed as Dance Celebrations to contend against such a definition, but the participants are still called folk dancers. So do I, introducing myself usually as a folk dance teacher just because this is the shortest way to refer to my field of activity.

I graduated from the university as a choreographer, have been teaching traditional and stage folk dance for about 25 years, and doing conscious, prepared and organised ethnochoreological dance research for the last eight years. Those two different activities have placed me in a borderline position between theory 
and practice, and this is where I start my search for the answer why the essence of the term 'folk dance' is constantly fluctuating in our minds.

Estonians often hold lively discussions about the term 'folk dance'; some of us express very clear principles about what is or is not the (Estonian) folk dance, and sometimes we do not understand each other because of the different meanings assigned to the term. Estonians are not the only ones to have these terminological problems. Similar arguments arise internationally, among dance scholars as well as enthusiasts. However, these discussions show that the topic is important for the discussants. To improve understanding between different parties, I would first like to show how the present situation has emerged in Estonia and then look for intersections between the different meanings attributed to the term 'folk dance'. The article provides an overview of changes in the concept of 'Estonian folk dance' in local theoretical and practical discourses.

\section{EARLIER RESEARCH, PROBLEMS AND THEORETICAL BACKGROUND}

Dance Words, a collection by Valerie Preston-Dunlop (1998), well illustrates the fragmented situation that had developed in dance theory and practice by the end of the 20th century. It provides several definitions of ethnic, folk, national and traditional dance, given by dance scholars, dancers, choreographers and writers and based on different classificators. Unfortunately, without an insight into the historical formation of concepts, the total set of explanations remains rather more confusing.

The historical development of the concept 'Estonian folk dance' has not been scientifically addressed before. However, the vagueness of the term 'folk dance' has been observed by many researchers worldwide (e.g. Hoerburger 1965, 1968; Hoppu 2004; Nahachewsky 1995, 2008), including Estonians (Tampere 1962, 1975; Torop 1992, 1995; Vissel 2004; Krause 2007). The concepts of folk and traditional music in Estonia have been thoroughly addressed and their changeability has been considered by Estonian ethnomusicologists Ingrid Rüütel (1987, 2004) and Taive Särg (2002, 2004, 2005, 2010; Särg \& Johanson 2011). Based on the analogy with music but taking into account the later emergence of interest in dances, it is maintained that the concept of 'Estonian folk dance' first started to evolve at the turn of the 19th century under the influence of the ideology of national romanticism, which idealised the lore and identity of Estonians as the peasantry.

Rüütel (2004: 221-222) provides several definitions of folk music, one of them stating that it is "music practiced in a community, no matter if based 
on oral traditions, publications or the media, and whether it changes or not", which resembles the classification of the folk dance as "any kind of dancing of ordinary people". As we will see further on in this article, such a definition, although useful for ethnochoreological research in contemporary communities, is still rarely used in Estonia, probably because of the aforementioned strong connection of the concept of folk dance with nationality ideas.

In traditional folklore studies, folk music is considered not professional and not connected with official institutions. Based on this, Särg (2005) would exclude secular choir singing and church music from the term 'folk music'. The practice termed as 'folk dance', on the contrary, often also constitutes a hobby, which in contemporary Estonia is very much influenced by professional teachers and choreographers well organised by NGOs or local governments, and to some extent even financially supported by the state. Therefore, the theoretical basis of folklore studies is not sufficient for addressing the concept of 'folk dance' nowadays; it has moved into the fields of specialised and professional culture, dance as an art form and performing arts in general.

In the article about the opportunities of Estonian folk dance research today (Kapper 2009), I used the term 'folk dance' in its broadest sense, including the dancing performed by any 'folk' (Dundes 2002) with any purpose, in the past and present, and also author choreographies. When approaching dance folklorism in Estonia at the turn of the 20th century (Kapper 2006, 2008), I narrowed the concept 'folk dance' down to peasantry dance traditions practised in their primary or secondary contexts (Honko 1998), and excluded author choreographies in order to distinguish between variable traditional dancing and the fixed rules of stage dance style. The need for this kind of distinction soon led to a wider introduction of the term 'traditional dance' (Estonian: pärimustants) in theoretical as well as practical discourses, which is described further on in this article.

Internationally, several definitions of 'folk dance' have been offered. The classification has been based on dance environment (it is a village dance), performer (the dance of members of certain national groups, the dance of commoners, the dance of amateurs as opposed to professionals), textual content (derived from ritual, agricultural, martial activities), or the identity of the recipient of the communicated message (a 'communal' dance, for the dancers themselves) (Nahachewsky 1995: 13). In a performer-based specification, the changed definition of 'folk' comprising everyone from (illiterate European) peasants to any group of people who share a common factor (Dundes 2002: 11-32), does its job well in theoretical discourse, but in the field of Estonian 'folk dance' practice the term 'folk' (Estonian: rahvas) tends to be mixed up with the word 'nation' (partially due to its similar sound in Estonian: rahvus), and through this connection once again coincides with (the romantic imaginations of) the peasantry. 
Young Estonian cultural theoretician Leenu Nigu (2011) has defined the 'Estonian national dance', meaning stage folk dance choreographies, as a style with certain movement vocabulary, sets of clearly defined national costumes and music, disciplined training system and choreographed mass spectacles, the repertoire of which conveys a shared idea of nationality and the performing of which reinforces the nation as an "affective community" (Gandhi 2006: 1-10). However, the invented tradition (Hobsbawm 1983) of 'national dance', hereinafter termed as 'stage(d) folk dance' is a living practice in Estonia ${ }^{3}$ now and, as such, is also interpreted by Nigu (2011). In popular discourse such dancing is also termed as rahvatants (folk dance). Sometimes the attribute 'stage(d)' is added, but it is often omitted. I suggested the corresponding Estonian term rahvuslik tants (national dance) in 2009 and it is sometimes used in specialist conversations but has not been put into wider circulation. This shows how theoretical discourse may provide tools for distinguishing new phenomena by naming them differently. Based on popular understandings, everyday use remains conservative because the distinction is not important or functional as we will see below.

As terms and concepts are in the focus of this writing, it is necessary to stress that I use the word 'concept' for thinking and knowledge units (Tavast 2004; Erelt 2007: 44), while 'terms' stand for vocabulary units in specialised discourses. A concept reflects a phenomenon in reality by way of its essential traits, connections and relations. Looking at dances in choreological perspective (Preston-Dunlop 2006), the essential traits of 'folk dance' - the movements and their qualities - are included in the main word of the expression ('dance'). The attribute 'folk' is critical for the dance context- and function-centred anthropological approach (Giurchescu \& Torp 1991; Royce 2002). By integrating choreology and anthropology into a holistic perspective, the expression 'folk dance' is addressed as a whole.

Dance has been studied as a communication process, where messages are sent between co-dancers or from the performer to the audience. All dance components (the movements, music, costumes, etc.) may change according to the relations and physical or cultural distance between the sender and the receiver (Kaeppler 1989: 451; Nahachewsky 1995: 1-6; Kapper 2009: 79-80). The phenomena commonly called 'folk dance' often differ along the participatory-presentational axis. Different message receivers and contexts of the communication process cause changes in the movement vocabulary and performing styles. These changes are especially remarkable when traditional folk dance forms in their authentic settings are compared to staged compositions.

Traditional folk dance 'in the field' and staged folk dance presentations have been referred to as parallel traditions (Shay 2002: 17-18), but as we can see in 
practice, those parallels cross, influence each other, and are connected to each other. This is also suggested by the theories of the first and second existence of folk dance (Hoerburger 1968: 30; Honko 1998), the "third existence dance" (Nahachewsky 1995: 13), which stands for social dance traditions influenced by revival activities, and the classification of folk dance revival strategies (Nahachewsky 2008). Lauri Honko (1998) has described folklore as a process that includes traditional practices within and for a social group but also outside collecting, archival recording and research, up to 'second life' phenomena like revival, use in cultural politics and commodification. Such a viewpoint justifies the anthropological view and use of the term 'folk dance' to signify dancing as part of folklore, to stand for the tradition as a continuous process in general, no matter how essential changes in choreographic texts are brought in. Nevertheless, in choreology and specialised discourses there has still been a need to discern also at least the two basic sub-phenomena (traditional/participatory and stage/presentational), especially because of epic differences between their movement content and performing styles. In the following analysis I explore the development of the Estonian folk dance in two main directions, concurrent changes in concepts, and static stability in terms during the 20th century and up to nowadays.

\section{SOURCES AND METHODS}

The research material - texts containing the word rahvatants (folk dance) published in Estonia from the end of the 19th century until 2009 - were analysed in diachronic order, highlighting the passages where the term 'folk dance' was used or the concept was defined. The materials can be divided into two main groups: reference books and periodicals. Under reference books belong Estonian general encyclopedias (Väike 1937; ENE) and specialised literature on the Estonian folk dance, both of which should be based on scientific classifications. Periodicals along with the Internet rather reflect popular understandings.

For the latter, I also questioned some contemporary folk dancers, members of a hobby group, 7 men and 9 women aged 30 to 49 years. It was a typical Estonian folk dance group, whose activities include physical training, high relative importance of author choreographies in the repertoire, recorded music for accompaniment, uniform costumes, etc. (Kapper 2008). On May 12, 2009, at the beginning of their usual rehearsal, I asked them to write what folk dance means for them personally. The information about the research project was given but no other discussions preceded the writing. I did not know those dancers before and they did not know much about my professional activities 
or opinions. Their answers were analysed using the method of conventional qualitative content analysis (Laherand 2008: 290-294), in which categories are found directly from the data.

Additionally, an important part of my data derives from personal ethnographic fieldwork conducted since 2004 in the world of Estonian folk dance. Records in my fieldwork diary comprise observation and participant observation data from different kinds of folk dance events like festivals, workshops, jams and parties, folk dancers' rehearsals, performed programmes, memos from organising meetings of the CIOFF Folklore Festival Baltica and Estonian Song and Dance Celebrations, quotations from conversations and ethnographic interviews with young and old dancers, members of local communities, folk dance groups and ensembles as well as unorganised enthusiasts, choreography students, dance teachers, producers, cultural managers, etc. My continuous fieldwork also encompasses the observation of Estonian folk dance-related discussions in the media, including social media (Facebook). Qualitative content analysis of the fieldwork diary texts in comparison and combination with the aforementioned materials forms the basis for my conclusions.

\section{FIRST INTEREST: FOLK DANCE AS ESTONIANS' OLD AND VALUABLE HERITAGE}

As Laugaste (1963: 101-110) has argued, the first lines about dance in Estonian folkloristics were written by Baltic German estophiles Fabricius (1610), Hupel (1767), Schlegel (1788, 1819), and others. Schlegel's vocabulary includes, for example, 'Tanz der Estnischen Nation', 'Tänze der Nation' and 'Nationaltanz', which means that the dances of another ethnic group, the cultural Other, are observed from the outside.

In 1892, journalist Georg Eduard Luiga wrote in the newspaper Olevik (The Present) ${ }^{4}$ :

Estonians also have their own old folk dances, [...] but are they still alive anywhere? [...] Folk dances convey the mode and habit of the folk and often express it more clearly than some other memories from old times. [...] Most of them are certainly gone, dancers are dead, but there are still old men who can do one or the other dance. (Luiga 1892: 636)

The 'folk' in the quotation still means the ethnic group, and two important opinions may be noticed:

- Folk dances include something characteristic of the 'folk', which is valuable; 
- Folk dances are old and disappearing and, therefore, they must be maintained artificially, e.g., by learning and notating from old people.

Luiga suggests that young men should learn dances from the old ones until "a smart guy invents a dance script so that folk dances can be preserved for researchers" (Luiga 1892: 636). Actually, dance notation systems existed in those times, but knowledge about them had probably not reached Estonia yet, or they were considered unsuitable for folk dance notation. ${ }^{5}$ So the lines in the newspaper started to embed in the popular mind the principles of classical folklore studies, which claimed that folklore, including folk dances, was old and existed in the memories of elderly people only, and that contemporary dance traditions and repertoire were of no interest.

As late as in 1913, Anna Raudkats, the first specially educated Estonian choreologist, who had learned folk dance notation at the Helsinki Gymnastics Institute, made her expeditions to Kolga rand (coast of Juminda Peninsula) on the northern coast, and Setumaa in the southwest of Estonia, which resulted in descriptions or mentioning of total 38 dances (EÜS X 1147/1335). Raudkats herself considered many of them as "modern salon dances with local names" (Tõnnus 1991: 21, 83) and did not appreciate them much; she was interested in notating older dance forms ${ }^{6}$, which would differ from contemporary fashionable dances and therefore fit into the repertoire of folk dance groups (Pomozi 2008: 129-130; Tõnnus 1991: 73-93). Thereby, the notion of 'true' and 'genuine' Estonian folk dance, supposedly reflecting earlier innocent and natural rural lifestyle, was established. Although Raudkats valued older dance forms more, she also notated the dances that were fashionable and circulated in Estonian villages at the beginning of the 20th century, nowadays sometimes referred to as old ballroom dances ${ }^{7}$.

Vanad seltskonnatantsud (Old Ballroom Dances) was the title of a book (VS 1997) containing notations of popular dances from the 1st half of the 20th century, first published as late as in 1997, which brought along an active use of those dances in the repertoire of Estonian folk dance groups. The dances that were not considered 'folk' by Raudkats and her contemporaries were then old enough to acquire this status. The term 'old ballroom dances' yet refers to the distinction made between them and earlier repertoire layers in specialised as well as popular discourses. Differentiation based on the short age and little variability of some old ballroom dances may be justified but functionally they do not differ from earlier types - social interaction and amusement were the main functions of peasantry dancing at least since contra dances (Põldmäe \& Tampere 1938: 33, 39; Torop 1995: 9) or earlier forms of couple dancing (Torop 1995: 22-23) appeared. Kristjan Torop (1995: 17) directly referred to the Es- 
tonian folk dance as "peasants' ballroom dance". The principle of amusement dancing among peasants reaches back to the Late Middle Ages also in Estonia (Russow 1993: 86).

In spite of this, in the sources published until the second decade of the 20th century, the Estonian folk dance is addressed as a part of folklore, a valuable witness of national history, which is unfortunately disappearing and must be saved by fixing in notations. Writers and notators, whether Estonians or not, exclude themselves from the 'folk', in whose dances they are interested.

\section{TWO DIRECTIONS}

Due to confusing times - World War I, the Estonian War of Independence, and the establishment of the Republic of Estonia - the dances collected by Anna Raudkats in 1913 were published only as late as in 1926. The publication of Raudkats's Eesti rahvatantsud (Estonian folk dances) reinforced the idea that 'folk dances' were supposed to be old-fashioned dances. The ones in actual circulation among ordinary Estonians in the period that the book was published did not qualify as 'folk dances' (Raudkats 1926: 8, 11). Such a choice was made due to romantic idealisation of rural peasant life and the wish to use dancing to support national identity feelings in the urbanising society. For that purpose, the collected dances were directly brought to stage to demonstrate their manifold values: Raudkats (ibid.: 9) was convinced that "national character is manifested in folk dances in its purest and most original format". As an educated gymnastics teacher she also emphasised health benefits gained from folk dance training, especially when certain instructions were followed, and she also believed that "folk dancing develops feelings of communion and arouses love and respect towards ancestors' traditions and arts" (ibid.: 10-14). The 'folk dancing' she advocates takes place mainly in school, group, and stage settings, which brings along a shift in the concept: from now on, 'folk dance' is the repertoire taught by teachers in groups and schools and performed on stages. Instead of rituals or amusement, the aim of folk dancing is physical exercise, aesthetic experience gained from displayed spectacles, and patriotic education.

Raudkats did not provide any literal definition of the Estonian folk dance; her position can be derived from her own writings and biography (Raudkats 1926; Tõnnus 1991). In the Estonian language, 'folk dance' (rahvatants) was first defined in Väike entsüklopeedia (Small Encyclopedia) as follows: "dances developed in peasant culture and characteristic of its spirit; main features usually internationally spread" (Väike 1937: 1247). Mentioning of the international character of the main features of folk dance is important in the scientific 
classification-based encyclopedia article, because it is different from the strong emphasis on national originality in practice. Later, in the Soviet period, the internationality of 'folk dances' was fully forgotten, and has slowly been re-found now, after Estonia regained independence. The encyclopedia article continues with folk dance typology by form and age, and three generally known folk dances are mentioned: labajalavalss, kaerajaan and tuljak. The written appearance of the latter gives an important hint - tuljak with the first character lowercase and without quotation marks certainly means the traditional dance, i.e., a folklore text and not the famous choreographed piece by A. Raudkats, which together with the above allows to conclude that this definition classifies the folk dance as part of folklore, omitting the revival movement or choreographers' art. The definition does not exactly say if 'folk dance' has to be old-fashioned, and therefore I looked up another article, 'ballroom dance' (seltskonnatants), in the same publication, which enumerates minuet, waltz, polka, tango, and foxtrot (Väike 1937: 1354), so the distinction between folk and ballroom dances remains somewhat unclear. I also looked for the term 'traditional dance' (pärimustants). There was no such entry in the book but the key word pärimus was there, with laconic reference to the term 'tradition' (ibid.: 1228).

The principle to classify old dance forms as 'folk dance' and leave living traditions aside was continued by Rudolf Põldmäe and Herbert Tampere (1938: 1-57), whose Valimik eesti rahvatantse (Selection of Estonian Folk Dances) in their interpretation "should provide an almost complete overview of our entire folk dance repertoire" (Põldmäe \& Tampere 1938: III). They also write:

The whole folk have participated in the creation of the folk dance and its taste is hidden in it. [...] Folk dancing should deepen our love for our ancestors and their creation, increasing the national identity of the youth. (Põldmäe \& Tampere 1938: 50)

Põldmäe and Tampere, however, suggest that "local revival activists should not forget folk dances of their surroundings" (Põldmäe \& Tampere 1938: 57 ) but, based on their background of classical folklore studies, they probably meant dances in the memories of elderly people rather than contemporary amusement of the youth. Similarly to Raudkats, Põldmäe and Tampere also refer to the healthiness of folk dance as physical exercise. The attitude that special training is required in order to perform folk dances (on stage) probably originates from this. The performing style exercised in groups and classes and shown on stage gradually changes according to the changed senders and recipients of the message.

Exceptionally, the folk music enthusiast August Pulst invited authentic performers to present their own dances at concert tours organised by him in 
1922-1936 (Vissel 2004: 113). While Raudkats sometimes stylised dances and always based them on at least minimal rules of performing arts, Pulst brought to the audience dances by traditional performers, without any arrangements or excess attention to the stage situation (ibid.: 112). Pulst was not an academically educated folklorist or dance teacher, and his common sense did not consider folk dances 'dead', as they were classified by the revival movement. The repertoire presented by Pulst resembled Raudkats's collection, and some of his dancers had also served as informants for the latter on her notation trips.

Hence, folk dance revival movement simultaneously started into different directions - folk dances were performed on stage in more or less stylised forms, and also new choreographies were created (Vissel 2004: 111-112), which in the beginning consisted mainly of new combinations of basic movements and fixed-format constructions according to certain pieces of music (e.g. Raudkats 1926: 51-66). Contemporary specialised literature (Raudkats 1926; Põldmäe \& Tampere 1938) and periodicals (A. R. 1926; R. S. 1932; Rändur 1933; T. L. 1935) diligently distinguish between 'original' folklore and folklorism. In case of adaptations or arrangements, books usually provide data of the choreographer. In the introduction of her book, Raudkats (1926: 7) declares which dances she has composed using different regional notations, and suggests that the reader should look at the original ones at the Estonian National Museum. Põldmäe and Tampere emphasise that dances are published in the original notation, just as they have been collected "from the folk" (Põldmäe \& Tampere 1938: III).

In periodicals the traditional folk dance is seen as part of ancient farm life, whereas stylisations and new creations fit into the modern educated (urban) life. The ancient is generally respected and highly valued, while the upstart disparaging attitude is condemnable (e.g. Rändur 1933), but the need to develop the nation's 'own culture' (Estonian: omakultuur) further, in accordance with modern requirements, is articulated. Stylising took place with folk art in general, e.g., in the elaboration of national costumes, and it also comprised the revival of past dances and creation of new folk-dance-based choreographies. As a further development, besides national ideals expressed in arrangements and choreographies, Raudkats (1926: 13-14) sees the clarity and accuracy of dance movements. Põldmäe and Tampere (1938: 49-57) are profound in their approach to folk traditions and at the same time tolerant to any directions of development. Thus during the first period of independence in Estonia the concept of 'folk dance' obtains a new dimension - in addition to its position as part of folklore, it is addressed as an art form (performing arts). This distinction is quite clearly made in scientific and specialised as well as popular discourses. 


\section{NATIONAL IN FORM, SOCIALIST IN CONTENT}

Further development of the Estonian folk dance was dashingly continued after World War II, when in the whole Eastern Europe folklorism was taken into use in cultural politics as an instrument for education and social change (Giurchescu 2001: 117). The transformation from social to artistic significance, and from variation to fixed forms (ibid.), was exactly what happened to 'folk dance'. These processes started earlier in parallel with normal developments in the field and were not only the consequence of the Soviet occupation; so in the following 50 years (1940-1990) the situation got out of balance. While folklore, including folk dance, was a process that was generally uncontrollable by any government or institution, it was logical to replace it by a strict selection, rules and norms of folklorism - without changing the term. From now on the Estonian folk dance, national in form, socialist in content, consisted in carefully selected stylised movements and presented on stage the hard-working, well trained, healthy and happy Estonians as part of the Soviet people. The promotion of folk dance and music was used to legitimise the Soviet system for foreigners and emphasise the seemingly democratic national policy and "flourishing of nations" (Mertelsmann 2003). The promotion of folk dance here unequivocally means the preference of the staged dance.

Specialised literature (Toomi 1947, 1953) still contains references to archival recordings, but published dance descriptions are rather different from the notations - choreographic texts have been improved and developed considerably, from standardised performing manners up to new parts added to the dances. The same books contain compositions based on original authorship, and partially due to this, folk dance is subordinated to the same requirements as author choreographies (Torop 2008: 12). In addition to the aforementioned standardisation, the mode how movements are executed is prescribed in a most strict and accurate way.

Standardisation and homogenisation are very useful in mass spectacles (Dance Celebrations), in which thousands of dancers simultaneously perform at a stadium and the artistic expression is created by their placement and synchronised movements. The great popularity and massive character of this phenomenon would even justify its name as 'folk dance', but choreography of those events is of a different style, which is characterised by expanded and synchronised movements, dancers trained according to specific character dancelike system based, in principle, on classical ballet, homogenised costumes, accompaniment of symphonic music, etc. The connection of the new stage style to folk traditions is loose, although single stylised elements of traditional folk dances may be used. 
Traditional folk dance forms have been hidden behind the new style for decades; folk dance groups do not perform them. In communities the existence of living traditions naturally continues and dance folklore is collected, from now on in addition to notations, also with the help of a film camera. In 1956 Milvi Sikk and Ingrid Rüütel notated tens of dances on Kihnu Island, in the 1960s the first eight hours of film material was shot in Pärnu County, on the islands of Saaremaa and Muhu, on Kihnu Island again, etc. (Vissel 1999: 57; ERA FAV 26 and DV 109-119), and in the 1970s Kristjan Torop started collecting dances in many places of Estonia (Vissel 1999: 58). The ongoing aim of folklorists was to store old and old-fashioned material, but now also many old ballroom dances were found sufficiently 'folk' and notated. Fashionable dances like tango, foxtrot, popular Latin dances or short-time favourites of the second half of the 20th century like lipsi or twist were not captured.

In the first decades of the Soviet period, the term 'folk dance' stood for the staged style only. This was proudly presented by the ruling ideology as national heritage - in fact, staged (ballet-based) character dance with new individual choreographies was presented. Folklore movement, which slowly developed in the 1970s and explosively spread at the end of the 1980s (Vissel 2004: 121), tried to turn back to traditional folk dance forms; often, however, with performing styles influenced by intermediary stage folk dance training. A glance into the Estonian Soviet Encyclopedia (ENE) confirms that two different concepts are signified with the term 'folk dance' - in the first edition it is defined as "traditional dance creation of the folk" (ENE 1970: 162; 1974: 384-385). The article describes the traditional folk dance and mentions stylisation as an opportunity. The final sentence of the article sounds period-specifically, reading: "In Soviet Estonia, special attention has been paid to folk dance", which clearly refers to stage style, based on what is indicated above. The second edition of ENE (1987: 448) contains a somewhat longer article titled Estonian Folk Dance, which also consists of an integrated overview of primary traditions, collection and publication of dances, and folk dance as a hobby and performing art. At the end of the article it says: "In the 1960s interest in folk dance heritage livened up. [...] There are genuine Estonian folk dances in the programmes of most folk dance groups" (ENE 1987: 448). Neither the extent of folk dance heritage nor the difference of genuine Estonian folk dances from the rest (non-genuine?) are explained in the encyclopedia.

Based on specialised literature and the realities of folklore studies indicated in this chapter, one can conclude that in scientific and specialised discourses two parallel concepts have been developed: firstly, the Estonian folk dance valued as national heritage, consisting of dances that have proved their 'traditional' and 'folk' character by a sufficiently long-term survival, and, secondly, the Estonian 
folk dance as a performing art and folklorism, which can be subordinated to artistic but also political choices and direction.

From the choreological point of view, dance movements show that during the Soviet period stage folk dance style obtained and reinforced its most characteristic traits so that instead of folklore studies the discourse to address it should have been dance studies - ethnochoreology and dance anthropology.

In public discourse, the Soviet regime used a common term 'folk dance' to keep folk dance as folklore and folk dance as performing art confused because this was beneficial - this way national values attributed to traditional folk dances during the national romanticism period and first period of independence in Estonia could be used in favour of legitimising the Soviet rule, although the dance content and performing style and manners had changed.

\section{RE-INDEPENDENT POSTMODERN ESTONIA}

The 1996 Explanatory Dictionary of Standard Estonian (EKSS) also defines folk dance as "traditional dance creation of the folk", just like ENE did in 1970; among examples, expressions such as "original folk dance" and "stylised folk dance" are provided (EKSS 1996: 804), whereby it is shown that folk dance may be 'original' - meaning traditional - or stylised and could be termed accordingly. The entry published in 1996 could have been written in the Soviet period and therefore reflects the ambiguous concept of 'folk dance' of that time. The second edition of the EKSS, published in 2009, changed neither the entry nor the explanation.

The EKSS was compiled by lexicographers from the Institute of the Estonian Language, and it is a profound description of the contemporary Estonian language, which should provide support in the understanding and research of the meaning of Estonian words (Keelevara 2009). The explanation of the word 'folk dance' (Estonian compound: rahvatants) itself clearly shows that the general concept of 'folk dance' is far from the "traditional dance creation of the folk" only: it also includes individual creation and choreographic activities, in which traditionality is not the determining aspect like in folk dance teaching in schools or groups, and folk dance as physical exercise. At the same time there is quite clear opposition between the two parts of the concept, which makes it more reasonable to define two different concepts instead of the confused and diffusive one.

In scientific and specialised discourses the need to find more suitable and exact terms for the different concepts of folk dance has resulted in several variants (Torop 2008: 11; Vissel 2004; Arraste 2008: 5) that are not presented here 
to save space, but that all in general still translate into English as 'traditional (authentic, original, genuine) folk dance' as opposed to 'stage folk dance'. The principal distinction is made on the participatory-presentational axis. In general and public discourses, both of those opposite poles are also referred to merely as 'folk dance', leaving out any specifying attributes.

Due to its presentational character, and the historical and political background addressed before in this article, stage dance has remained more visible in society, which has led to the inclination of the concept of 'Estonian folk dance' towards stage style. In re-independent Estonia, stage folk dance obtained the main and principal position within the notion 'folk dance'. So to say, the term 'folk dance' was occupied by the stage style concept and reality.

For the notion 'traditional folk dance', therefore, a new term was necessary to distinguish between two possible styles. A new word pärimustants ${ }^{8}$ was coined for this purpose, partially inspired by the term pärimusmuusika (traditional music), which since the 1990s had been used to distinguish old rural music styles and their contemporary adaptations from adaptations of musical folklore made according to Soviet ideology, popularly termed as rahvamuusika (folk music) (Särg \& Johanson 2011: 137).

Four editions of the Dictionary of Estonian Folk Dance Terminology (Torop 2008) do not include the word pärimustants (traditional folk dance) as a defined term or key word, ${ }^{9}$ nor do contemporary dictionaries of the Estonian language $(\text { EKSS 1996, 2009 })^{10}$. In academic writing, the term pärimustants was first used by Estonian ethnomusicologist and dance researcher Anu Vissel (2004: 125) to mark the dancing that preceded stage folk dance style and from which the latter was evolved. Ingrid Rüütel (2009: 53, 74) signified by the term pärimustants traditional folk dance texts that might circulate "in their traditional and modern context". At the same time, the use of the term pärimustants among some traditional music and dance lovers could also be noticed (Kapper 2009: 79). Google search on November 25, 2009, showed that the word pärimustants most often appeared in connection with the Estonian Traditional Music Center ${ }^{11}$ (ETMC), being mainly contained in introductions of short training programmes, curricula of music and hobby schools, and an innovative dance production by traditional dance enthusiasts. A new search three years later, on September 20, 2012, showed a remarkable growth in numbers but the context had remained similar: hobby education, training courses and workshops. In addition to the ETMC, the word was now used in web publications of many other organisations and institutions active in the field of research as well as training and cultural management. ${ }^{12}$ This shows how the latter as mediators between theoretical and practical discourses have started to actively spread the new term and concept coined in scientific research on the one hand, and inspired by popular understanding of traditional music on the other. 
By now, in popular understanding, the concept of pärimustants is still a little narrower than the concept of pärimusmuusika, which, according to Särg and Johanson (2011: 137), includes contemporary adaptations - traditional folk dance enthusiasts are rather cautious in respect of any artificial arrangements. Traditional folk dance lovers first emphasised its variability and improvisational character as a basic difference from stage folk dance (e.g., charismatic artists Jaak Johanson and Silver Sepp in Haav 2009; Meiessaar 2009; Kapper 2010). Dismissive feelings in respect of arrangements were caused by the knowledge about Soviet stage style adaptations, in which individual and local, regional and other communal peculiarities arising from improvisation were suppressed and replaced with standardisation. On the other hand, emphasis was put on the changeability of pärimustants in contrast to folklorism fostered within folklore movement, which was considered to over-idealise, imitate and cultivate fixed dance forms instead of accepting the changeability of living traditions.

However, all concepts are within their continuous dynamics, and by 2012 , based on discussions and practical experience, I was able to confirm that radical distancing of the concept 'traditional folk dance' from 'folk dance' in general was turning into a rather constructive search for alternative methods in adapting folk dance material collected by folklorists to contemporary aesthetics and lifestyles, without decreasing the high value attached to the dancer's individuality.

It is remarkable and, in light of the above, not surprising that there were no such categories as 'variability', 'improvisational', 'individual' or 'personal' in the answers given in 2009 by the members of the folk dance group questioned about their own understanding of 'folk dance'. Rather opposite categories as 'stable in time', 'old', and 'lasting from generation to generation' were highlighted in qualitative content analysis. These categories refer to the existence of the concept of 'traditional folk dance' also in the respondents' minds, as different features of the phenomenon are seen.

Another important category mentioned in the texts by the folk dance group members was 'nationality', which is less visible in connection with the concept and realities of 'traditional folk dance'. Based on traditional dance enthusiasts' statements in personal conversations and social media, I would say that tolerance and knowledge of internationally common features is greater among them. Local and regional peculiarities are of special interest in folklore movement (e.g., CIOFF Definitions 2012), but the all-Estonian national level is hidden behind them or left aside - maybe this can be seen as an expression of protest against stage-style standardisation. Performing groups typically reinforce their national expression with national costumes (which were also mentioned by dancers as a characteristic of folk dance), while traditional folk dance enthusiasts usually wear ordinary everyday clothing at their participatory events. 
Folk dance group members repeatedly defined folk dance by its functions, among which '(social) communication', 'amusement', 'education', 'physical exercise' and 'artistic expression' were named. I did not ask, but a dancer explained that "author choreographies are also folk dances". For that person, physical exercise and artistic expression were important qualities of folk dance, which refers to the concept of 'stage folk dance' rather than 'folk dance' in general. For several dancers, the complex how 'folk dance' functioned for them included traits from both concepts - traditional and stage. This refers to intermingling of presentational and participatory dance in folk dance group settings, which has also been noticed before: Torop (2008: 15) mentions in the definition of 'folk dance group' that folk dances are learned there just for fun or for presentation. I would use 'and' instead of 'or' because they both occur at the same time but are of different importance, depending on the inner culture of the group, value judgements, activity period or concrete situation (Kapper 2006; Nahachewsky 2008). The presence of both participatory and presentational categories was confirmed by the folk dance functions listed by dancers, and likewise the fact that the concept of 'stage folk dance' fits well into their broader concept of 'folk dance'.

All the answers of the folk dance group members were unique, and as unique are traditional folk dance enthusiasts' statements in the media and conversations. Concepts expressed in words are not always in full accordance with reality but reflect dreams and wishes about how things should be. Real dancing is almost as diverse as the above opinions. Postmodern fragmentation has reached the world of 'Estonian folk dance'. Nowadays everybody can find a community with certain values to adjust to or create a community according to his or her own beliefs and convictions.

\section{DISCUSSION}

After this diachronic analysis of changes, which have taken place in the terms and concepts reflecting the realities of 'Estonian folk dance', we can proceed to the intersections found between different classifications and discourses. To understand the mutual influences of theories and practices, some additional historical information about different revival activities is also provided in this section.

Starting from the first records, folklorists have defined Estonian folk dances as belonging to the past of a group positioned outside the collectors and researchers. The attitude to folk dance as an old-fashioned phenomenon vanishing with elder generations, and deriving from classical folklore studies, spread 
via publications and the media throughout nearly the entire 20 th century. The classification of folk dance as something different and 'other' makes it possible to relocate it from participatory to presentational settings: from everyday life of the peasantry onto the stage in front of a passive audience, and that is what happens in practice.

Since 1920, the Estonian folk dance in its presentational forms has been used in cultural politics - until 1940 for the purposes of patriotic and national education, in 1940-1990 to legitimise and propagate the socialist order, and since the 1990s (actually already from the second half of the 1980s, the Singing Revolution era) to reinforce the newly found national identity within the regained independence of Estonia. During the first period of independence in Estonia as well as in the Soviet period, stage folk dance was of little interest for folklorists and in scientific discourse in general. ${ }^{13}$ Therefore its differences from traditional dancing were neither analysed nor explained in public. Such silence in academic discourse and good visibility of the dance in presentational settings have resulted in widespread public understanding that nowadays stage folk dance is the only and regular further development of the folk dance, which corresponds to the requirements of contemporary society.

Based on researchers and students' interest in folklore from the past, including past dance forms, at the end of the 1960s, some pioneers of authentic folklore movement started their practice that explosively grew at the turn of the 1980s, but the leading position of stage folk dance was never completely balanced out. Dance folklorism exercised by folklore groups still mainly consisted in presentational dancing of 'original' forms learned from archival collections and performed with minor arrangements or almost without them. The term used for this kind of dancing was sometimes 'folk dance', but due to the strong connection of that term to stage folk dance, other opportunities were searched for. ${ }^{14}$ In scientific discourse, this revival phenomenon is classified as the second life of folklore, dances performed in presentational settings are also recorded for folklore archives, and changes in them are analysed as folklore texts. For public understanding there is no big difference from stage folk dance, although scientific research may point out many typical alternations.

The other revival movement, dance $\operatorname{clubs}^{15}$, started at the beginning of the 1990s as a general protest against any kind of presentational dancing, is the expression of a slightly different concept of 'folk dance'. For a period, in the rhetorics of dance club activists, stage folk dance and dance folklorism were considered principally the same (and condemnable), and high value was attached to participatory dancing. The dance club movement was first initiated and has until now been mainly led by musicians. It is different from other revival phenomena, and similar to authentic participatory situations that usu- 
ally depend on musicians. During the twenty years of dance club history, its participatory settings and live contact between dancers and musicians have really led to a living tradition that is carried on by a number of core enthusiasts, varies according to several factors like dancing locations, regions, music, dancers' personalities, emotional situation, etc., and still maintains some of its characteristic features through times.

Besides dance clubs, folklore groups' activities and festivals there are other settings for traditional folk dance in contemporary Estonia - training courses, workshops, traditional music concerts, parties, jams, etc., which mostly promote participatory dancing providing conditions for practising. The activity is then termed as pärimustants (traditional folk dance), just tants (dance), or sometimes signified with a wordplay rahva tants (literally: dance of the folk, meaning - dance of ordinary people).

Since 2009, there have also been single cases of bringing traditional folk dance into presentational settings on a level qualitatively different from stage folk dance. Those attempts are also initiated by (dancing) musicians and generally follow the route of contemporary traditional music in search of its 'internal authenticity' (Särg \& Johanson 2011: 138). Along with stage folk dance, those new directions of traditional folk dance are also appreciated, observed and analysed by dance researchers of today. In public understanding, at the moment, 'folk dance' (rahvatants) is mainly presentational and equals to 'stage folk dance', also referred to as 'national (stage) dance' (rahvuslik (lava)tants) while the concept of 'traditional folk dance' (pärimustants) ranges from old peasantry dance forms to their different uses in today's practice.

\section{IN CONCLUSION}

Within the general concept of 'folk dance', however, in addition to the abovediscussed common elements present in scientific as well as public classification, some discrepancies have attracted my attention.

In scientific as well as popular classification, quite a clear distinction is made between author choreography and so-called folk creation, in which the author is unknown or not important. Although both of them are termed 'folk dance', the specifying attributes available in public discourse are not always considered necessary. But author choreography and folk creation, so clearly distinguishable from each other in both classifications, turn out undifferentiated in presentational situations, when they are performed by dancers in national costumes. Then both stand for national expression in a visible and bodily format, and the origin of movement motifs or performing style does not matter. 
Choreographic text, of course, gives the sense of origin - the much more sophisticated movement vocabulary and complicated composition of choreographed pieces with usually quite standardised and homogenised performing style and other typically presentational details let us easily understand that there is no traditional folk dance in question. But such a movement-based perspective is interesting for researchers and folk dance specialists or enthusiasts; in wider public understanding the movement content of a dance is not the basis for classifying a phenomenon as 'folk dance', and even less as 'stage folk dance' or 'traditional folk dance'.

\section{NOTES}

1 The research was supported by ETF grants 7231 and 9132, the target-financed research topic SF 0130033s07 and the Centre of Excellence in Cultural Theory (project TK18U01).

${ }^{2}$ For the history of the Estonian Song and Dance Celebration traditions as a UNESCO masterpiece of the Oral and Intangible Heritage of Humanity see http://laulupidu.ee/ english/history/, last accessed on August 2, 2013.

3 As well as in most European countries.

4 Translation from Estonian here and hereinafter by Sille Kapper.

5 E.g. Beauchamps-Feuillet system widely used in the 18th century Europe for baroque dance notation, or the Stepanov notation for ballet in Russia.

${ }^{6}$ Mainly circle, chain, and contra dance types named Voortants, Saba tants, Rädi tants, Ingliska, Kadrel, Kargus, etc., and some earlier forms of couple dances (EÜS X $1213 / 1249<$ Raudkats (1913)).

7 Waltz, polka, schottische, and local forms of internationally spread one-melody couple dances, e.g., Krakuiak, Karobotska, etc. (EÜS X 1319/1421 < Raudkats (1913)).

8 The direct translation would be 'traditional dance', but to keep the connection with the general term for both parts of the concept of 'folk dance', the expression 'traditional folk dance' is used in this article.

9 Although its synonym rahvapärimuslik tants is used in movement descriptions (Torop 2008a: 31).

${ }^{10}$ However, pärimusmuusika (traditional folk music) is included in EKSS 2009 with a laconic explanation as rahvamuusika (folk music), as well as pärimus (oral lore, oral tradition) and pärimuslik (traditional).

${ }^{11}$ An NGO that organises traditional music festivals, concerts, trainings, etc. (Statutes 2012). 
12 Training Center of Estonian National Folklore Council, the Folk Culture Centre, the Estonian Folk Dance and Folk Music Association, Tallinn University, the University of Tartu, the Estonian Literary Museum, etc.

13 This happened not only in Estonia and the USSR. Anthony Shay (2002), when starting his research on state folk dance companies, claimed the same about the whole world.

${ }^{14}$ E.g. folkloorne tants that does not translate very well into English but means something like 'dance as part of folklore', and since approximately the second half of the first decade of the 21 st century, also pärimustants (traditional folk dance).

${ }^{15}$ Dance club (Estonian: tantsuklubi) is an informal social movement for practicing traditional folk dances mainly derived from Estonian villages from the end of the 19th and beginning of the 20th centuries. The movement started following the example of Hungarian táncház. Regular events are held in Tallinn and Tartu every two weeks, occasionally also in other places.

\section{ARCHIVAL SOURCES}

ERA - Estonian Folklore Archives

EÜS - Folklore collection of the Estonian Students Society in the Estonian Folklore Archives

FAV - Analogue videos in the Estonian Folklore Archives

DV - Digital videos in the Estonian Folklore Archives

\section{MANUSCRIPT SOURCES}

Sille Kapper's fieldwork materials in the possession of the author.

\section{REFERENCES}

A. R. 1926. Eesti rahvatantsud. [Estonian Folk Dances.] Postimees (newspaper), August 21, p. 3.

Arraste, Angela 2008. Saateks. [Foreword.] In: K. Torop: Eesti rahvatantsu oskussõnastik. Tallinn: Rahvakultuuri Arendus- ja Koolituskeskus, p. 5.

CIOFF Definitions $2012=$ CIOFF Definitions of Traditional Programs on the Stage 2012. Tallinn: ERFN. Available at http://www.folkloorinoukogu.ee/CIOFF_Definitions_ of_Traditional_353.htm, last accessed on August 2, 2013.

Dundes, Alan 2002. Kes on rahvas? [Who Are the Folk?] Tallinn: Varrak.

ENE 1970 = Eesti Nõukogude Entsüklopeedia 2. [Estonian Soviet Encyclopedia.] Tallinn: Valgus.

ENE 1974 = Eesti Nõukogude Entsüklopeedia 6. [Estonian Soviet Encyclopedia.] Tallinn: Valgus. 
ENE 1987 = Eesti Nõukogude Entsüklopeedia 2. [Estonian Soviet Encyclopedia.] Tallinn: Valgus.

EKSS 1996 = Eesti kirjakeele seletussõnaraamat. IV köide, 4. vihik. [Explanatory Dictionary of Standard Estonian.] R. Karelson \& V. Kullus (chief eds.). Tallinn: Eesti Teaduste Akadeemia Eesti Keele Instituut.

EKSS 2009 = Eesti keele seletav sõnaraamat. [Explanatory Dictionary of Standard Estonian.] R. Karelson \& V. Kullus et al. (eds.). Tallinn: Eesti Keele Sihtasutus. Available at http://www.eki.ee/dict/ekss/ekss.html, last accessed on August 2, 2013.

Erelt, Tiiu 2007. Terminiõpetus. [Textbook of Terminology.] Tartu: Tartu Ülikooli Kirjastus.

Gandhi, Leela 2006. Affective Communities: Anticolonial Thought, Fin-de-Siécle Radicalism, and the Politics of Friendship. Duke University Press.

Giurchescu, Anca 2001. The Power of Dance and Its Social and Political Uses. Yearbook for Traditional Music, Vol. 33. Canberra: International Council for Traditional Music, pp. 109-121, http://dx.doi.org/10.2307/1519635.

Giurchescu, Anca \& Torp, Lisbet 1991. Theory and Methods in Dance Research: A European Approach to the Holistic Study of Dance. Yearbook for Traditional Music, Vol. 23. Canberra: International Council for Traditional Music, pp. 1-10, http://dx.doi.org/10.2307/768392.

Haav, Margus 2009. Jaak Johansoni ja Silver Sepa tantsuetendus taastab hääbunud sidet. [Dance Production by Jaak Johanson and Silver Sepp Restores the Vanished Connection.] Postimees (newspaper), November 12. Available at http://www. postimees.ee/?id=187022, last accessed on August 2, 2013.

Hobsbawm, Eric 1983. Introduction: Inventing Traditions. In: Eric Hobsbawm \& Terence Ranger (eds.) The Invention of Tradition. Cambridge: Cambridge University Press, pp. 1-14.

Hoerburger, Felix 1965. Folk Dance Survey. Journal of the International Folk Music Council, Vol. 17, part 1, pp. 7-8.

Hoerburger, Felix 1968. Once Again: On the Concept of "Folk Dance". Journal of the International Folk Music Council, Vol. 20, pp. 30-32.

Honko, Lauri 1998 [1990]. Folklooriprotsess. [The Folklore Process.] Mäetagused: Hüperajakiri, Vol. 6, pp. 56-84. Available at http://www.folklore.ee/tagused/ nr6/honko.htm, last accessed on August 2, 2013. [Original: Hanko, Lauri 1990. Folkloreprosessi. Sananjalka 32, 1990, pp. 93-119.]

Hoppu, Petri 2004. Tantsufolklorism tänapäeva Soomes. [Dance Folklorism in Finland Today.] In: I. Rüütel (comp.) Pärimusmuusika muutuvas ühiskonnas 2. Töid etnomusikoloogia alalt 2. Tallinn: Eesti Kirjandusmuuseumi etnomusikoloogia osakond \& Eesti Rahvuslik Folkloorinõukogu, pp. 97-101.

Kaeppler, Adrienne L. 1989. Dance. In: E. Barnouw (ed.) International Encyclopedia of Communications 1. New York: Oxford University Press, pp. 450-454.

Kapper, Sille 2006. Tantsufolklorismist tänases Eestis. Folkloorse tantsu harrastamisest Eestis 1995-2005. [Dance Folklorism in Estonia Today. Folk Dance as a Hobby Activity in Estonia 1995-2005.] Master's thesis. Tallinn: Tallinna Ülikool.

Kapper, Sille 2008. Tantsufolklorismist tänases Eestis. [Dance Folklorism in Estonia Today.] In: M. Hiiemäe \& J. Oras \& L. Saarlo (eds.) Tonditosin. Tartu: Eesti Kirjandusmuuseumi Teaduskirjastus, pp. 24-52. 
Kapper, Sille 2009. Kuidas uurida eesti rahvatantsu tänapäeval? Teooriatest, meetoditest ja nende rakendamisest Eestis. [How to Conduct Research on Estonian Folk Dance Today?] Mäetagused: Hüperajakiri, Vol. 41. Tartu: Eesti Kirjandusmuuseum, pp. 75-98. Available at http://www.folklore.ee/tagused/nr41/kapper.pdf, last accessed on August 2, 2013.

Kapper, Sille 2010. Seest tuleb üks tants - tantsune muusik. Intervjuu Silver Sepaga. [The Dance Comes from Inside: A Dancing Musician. Interview with Silver Sepp.] Sirp (newspaper) No. 26, July 22. Tallinn: SA Kultuurileht. Available at http:// www.sirp.ee/index.php?option=com_content\&view=article\&id=10944:seest-tulebueks-tants--tantsune-muusik-\&catid=5:muusika\&Itemid=12\&issue=3305, last accessed on August 2, 2013.

Keelevara. [Languageware.] Available at http://www.keelevara.ee/teosed/seletav/, last accessed on August 2, 2013.

Krause, Katrin 2007. Rahvatantsu imago noorte ühiskonnas: uurimus 11-18-aastaste noorte seas. [Image of Folk Dance in Youth Society: Research among 11-18-YearOlds.] Master's thesis. Tallinn: Eesti Muusika- ja Teatriakadeemia.

Laugaste, Eduard 1963. Eesti rahvaluuleteaduse ajalugu: valitud tekste ja pilte. [History of Estonian Folklore Research: Selected Texts and Pictures.] Tallinn: Eesti Riiklik Kirjastus.

Laherand, Meri-Liis 2008. Kvalitatiivne uurimisviis. [Qualitative Research.] Tallinn: Infotrükk.

Luiga, Georg E. 1892. Rahwa tantsud. [Folk dances.] Olevik (newspaper) No. 31, p. 636.

Meiessaar, Maris 2009. Silver Sepp vahendab pärimustantsu keemilisi hetki. [Silver Sepp is Mediating Chemical Moments of Traditional Folk Dance.] Eesti Päevaleht (newspaper), November 14. Available at http://www.epl.ee/artikkel/482623, last accessed on August 2, 2013.

Mertelsmann, Olav 2003. Hariduse ja kultuuri ekspansioon süsteemi stabiliseerijana Eestis 1940-1956. [Expansion of Education and Culture as System Stabiliser in Estonia in 1940-1956.] Kultuur ja Elu (magazine), No. 3. Available at http:// kultuur.elu.ee/ke473_haridus.htm, last accessed on August 2, 2013.

Nahachewsky, Andriy 1995. Participatory and Presentational Dance as Ethnochoreological Categories. Dance Research Journal, Vol. 27, No. 1 (Spring), pp. 1-15, http://dx.doi. org/10.2307/1478426.

Nahachewsky, Andriy 2008. Folk Dance Revival Strategies. Ethnologies, Vol. 30, No. 1, pp. 41-57, http://dx.doi.org/10.7202/018834ar.

Nigu, Leenu 2011. Stomping Step Makes Us Estonian: Dancing the Pristine Ethos of a Nation. In: People Make Places: Ways of Feeling the World. SIEF Congress programme and book of abstracts. April 17-20. Lisbon: CRIA. Available at http:// www.nomadit.co.uk/sief/sief2011/panels.php5?PanelID=815, last accessed on August 2, 2013.

Põldmäe, Rudolf \& Tampere, Herbert 1938. Valimik eesti rahvatantse. [Selection of Estonian Folk Dances.] Tartu: Eesti Rahvaluule Arhiivi Toimetused 8.

Pomozi, Eda 2008. Setumaa tantsupärimusest Euroopa tantsuajaloo kontekstis. [Dance Traditions of Setumaa in the Context of European Dance History.] In: M. Hiiemäe \& J. Oras \& L. Saarlo (eds.) Tonditosin. Tartu: Eesti Kirjandusmuuseum, pp. 129-159. 
Preston-Dunlop, Valerie 1998. Dance words. Amsterdam: Harwood Academic Publishers.

Preston-Dunlop, Valerie 2006. Looking at Dances: A Choreological Perspective on Choreography. Ightham: Verve.

Rändur, V. P. 1933. Eesti omapärase tantsu uuestisünd. [Rebirth of Original Estonian Dance.] Postimees (newspaper), December 9, p. 6.

Raudkats, Anna 1926. Eesti rahvatantsud. [Estonian Folk Dances.] Tartu: Postimees. Royce, Anya P. 2002. The Anthropology of Dance. Alton: Dance Books Ltd.

R. S. 1932. Stiliseeritud rahvatantsud "Vanemuises". [Stylised Folk Dances at Vanemuine Theatre.] Postimees (newspaper), May 27, p. 5.

Russow, Balthasar 1993. Liivimaa kroonika. [The Chronicle of Henry of Livonia.] Tallinn: Hotger.

Rüütel, Ingrid 1987. Folkloor ja tänapäeva kultuur. [Folklore and Contemporary Culture.] Kultuur ja Elu (magazine), No. 5, pp. 11-15.

Rüütel, Ingrid 2004. Pärimusmuusika tänapäeva ühiskonnas. [Traditional Music in Contemporary Society.] In: J. Ross (comp. \& ed.) \& K. Maimets (ed.) Mõeldes muusikast: sissevaateid muusikateadusesse. Tallinn: Varrak, pp. 220-243.

Rüütel, Ingrid 2009. Kihnu pärimustantsud minevikus ja tänapäeval. [Traditional Dances of the Kihnu Island, Estonia.] Mäetagused: Hüperajakiri, Vol. 41, pp. 53-74. Available at http://www.folklore.ee/tagused/nr41/ryytel.pdf, last accessed on August 2, 2013.

Särg, Taive 2002. Rahvamuusika mõiste kujunemisest “rahva”teaduste ja musikoloogia vahel. [On the Formation of the Concept of Folk Music between 'Folk'-Sciences and Musicology.] In: T. Ojamaa\& I. Rüütel (comps. \& eds.) Pärimusmuusika muutuvas ühiskonnas 1. Töid etnomusikoloogia alalt 1. Tartu: Eesti Kirjandusmuuseumi etnomusikoloogia osakond, pp. 9-44.

Särg, Taive 2004. Mis on eesti rahvamuusika? [What is Estonian Folk Music?] In: J. Ross (comp.), J. Ross \& K. Maimets (eds.) Mõeldes muusikast: sissevaateid muusikateadusesse. Tallinn: Varrak, pp. 125-159.

Särg, Taive 2005. Rahvamuusika mõiste ja kontseptsiooni kujunemisest Eestis. [On the Formation of the Concept of Folk Music in Estonia.] In: T. Ojamaa (comp.) \& T. Särg \& K. Labi (eds.) Pärimusmuusikast popmuusikani. Töid etnomusikoloogia alalt 3. Tartu: Eesti Kirjandusmuuseumi etnomusikoloogia osakond, pp. 13-48.

Särg, Taive 2010. Ehedus mitut moodi: rahvamuusika ahtusest pärimusmuusika avarustesse. [Different Authenticities: From the Narrowness of Folk Music to the Spaciousness of Traditional Music.] Keel ja Kirjandus (magazine), No. 8/9, pp. 639-654.

Särg, Taive \& Johanson, Ants 2011. Pärimusmuusika mõiste ja kontseptsiooni kujunemine Eestis. [Development of the Term and Conception of the Traditional Music in Estonia.] Mäetagused: Hüperajakiri, Vol. 49. Tartu: Eesti Kirjandusmuuseum, pp. 115-138. Available at http://www.folklore.ee/tagused/nr49/parimusmuusika. pdf, last accessed on August 2, 2013.

Shay, Anthony 2002. Choreographic Politics. State Folk Dance Companies, Representation and Power. Middletown: Wesleyan University Press.

Statutes 2012. Eesti Pärimusmuusika Keskus. [Estonian Traditional Music Center.] Viljandi: EPMK. Available at http://www.folk.ee/en/Introduction/Statutes, last accessed on August 2, 2013. 
Tampere, Herbert 1962. Eesti rahvatantsu ajaloost. [On the History of Estonian Folk Dance.] Tallinn: Eesti NSV Rahvaloomingu Maja.

Tampere, Herbert 1975. Eesti rahvapillid ja rahvatantsud. [Estonian Folk Music Instruments and Folk Dances.] Tallinn: Eesti Raamat.

Tavast, Arvi 2004. Mõiste mõiste: tähendusteooriate mõju oskuskeelepraktikale. [Concept of Concept: Influence of Theories of Meaning on Terminology Practice.] In: Rahvusvaheline terminoloogiakonverents "Eesti oskuskeel 2003", 10. ja 11. oktoobril 2003. Ettekanded. [Terminology Conference Estonian LSP 2003.] Tallinn: Eesti Keele Sihtasutus, pp. 7-18.

T. L. 1935. Elmerice Partsi lastetantsud. [Children's Dances by Elmerice Parts.] Postimees (newspaper), April 12, p. 7.

Tõnnus, Richard 1991. Anna Raudkats oma ajas. [Anna Raudkats in Her Time.] Tallinn: Eesti Raamat.

Toomi, Ullo 1947. Valimik eesti rahvatantse. [Selection of Estonian Folk Dances.] Tallinn: Ilukirjandus ja Kunst.

Toomi, Ullo 1953. Eesti rahvatantsud. [Estonian Folk Dances.] Tallinn: Eesti Riiklik Kirjastus.

Torop, Kristjan 1992. Endisaegse Virumaa tantsuvõimalused ja tantsud. [Dance Opportunities and Dances in Historical Virumaa.] In: I. Rüütel (comp. \& ed.) IdaVirumaa rahvakultuurist. Tallinn: Virumaa Fond, Eesti TA KKI folkloristikaosakond, pp. 132-147.

Torop, Kristjan 1995. Kontratantsud. [Contra Dances.] Tallinn: Rahvakultuuri Arendusja Koolituskeskus \& Eesti Keele Instituut.

Torop, Kristjan 2008 [1966]. Eesti rahvatantsu oskussõnastik. [Glossary of Estonian Folk Dance Terminology.] Ü. Feršel (ed.). Tallinn: Rahvakultuuri Arendus- ja Koolituskeskus.

Väike 1937 = Väike entsüklopeedia. [Small Encyclopedia.] R. Kleis (chief ed.). Tartu: K./Ü. Loodus.

Vissel, Anu 1999. Ülevaade varasematest töödest eesti rahvatantsu kogumisel ja arhiveerimisel Eesti Rahvaluule Arhiivi materjalide põhjal. [Overview of Earlier Works on Collecting and Archiving of Estonian Folk Dance, Based on Estonian Folklore Archives.] In: Rahvatantsu uurimine: arhiivid, meetodid, teooriad. Viljandi: Viljandi Kultuurikolledž, pp. 54-60.

Vissel, Anu 2004. Rahvatantsu asendist eestlaste kultuuripildis ja harrastustes. [The Position of Folk Dance in the Culture and Hobbies of Estonians.] In: I. Rüütel (comp.) Pärimusmuusika muutuvas ühiskonnas 2. Töid etnomusikoloogia alalt 2. Tartu: Eesti Kirjandusmuuseumi etnomusikoloogia osakond \& Eesti Rahvuslik Folkloorinõukogu, pp. 109-127.

VS 1997 = Aassalu, Heino \& Luht, Pille \& Torop, Kristjan (comps.) Vanad seltskonnatantsud. Valimik XX sajandi I poole seltskonnatantse. [Old Ballroom Dances. Selection of Social Dances from the 1st Half of the 20th Century.] Tallinn: Rahvakultuuri Arendus- ja Koolituskeskus. 